TAPROBANICA, ISSN 1800-427X. April, 2013. Vol. 05, No. 01: pp. 81-84.

(C) Taprobanica Private Limited, 146, Kendalanda, Homagama, Sri Lanka.

www.taprobanica.org

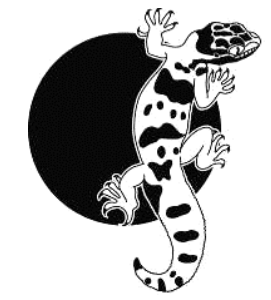

\section{The Indian Golden Gecko, Calodactylodes aureus (Beddome, 1870) in Tamil Nadu, India}

The gekkonid lizard genus Calodactylodes Strand, 1926 is endemic to peninsular India and Sri Lanka (Bauer \& Das, 2000). Calodactylodes aureus (Beddome, 1870), the first described species in the genus, was originally recorded from the Tirupati Hills, Andhra Pradesh state in India (Daniel et al., 1986). In Andhra Pradesh, in addition to the type locality, it is recorded from the Araku Valley (Chettri \& Bhupathy, 2010) and the Ananthagiri Hills (Sreekar et al., 2010) both in the Visakhapatnam District, from Perantalapally in the Khammam District (Javed et al., 2007; Sreekar et al., 2010), from Maredumilli in the East Godavari District (Sreekar et al., 2010), the Seshachalam Hills in Chittoor and Kadapa Districts (Guptha et al., 2012) and the Tirumala Hills in Chittoor District (Nanda Kumar et al., 2000). In Orissa state the species has been reported from Rayagada and Kalahandi Districts in the Niyamgiri Hills (Dutta et al., 2005). Finally, in the state of Tamil Nadu the species has been recorded from the Balamathi, Valli Malai and Sathgar Hills in Vellore District, Nedumkunam Hill in Tiruvannamalai District and Shyed Basha Malai in Krishnagiri District (Bauer \& Das, 2000; Rajashekhar \& Nanda Kumar, 2007; Kalaimani \& Nath, 2012).

The Indian Golden Gecko is a protected species and is included in Schedule I (Part II) of the Indian Wildlife (Protection) Act, 1972. In this paper, we discuss the current status of $C$. aureus, including its conservation, ecology, threats and recent distribution patterns from study locations at Melthiruvadathanur (Morambu), Karadi Parai and Sathanur Dam in Tiruvannamalai District, the Gingee Hills (7043.74 ha.) in Villupuram District and the Kailasagiri Hill (Ambur) in the Vellore District of Tamil Nadu state.
This paper is mainly based on the data collected by the authors during field visits totaling 47 days undertaken between December 2010 and April 2011. We searched all suitable habitats within a given area. At each site where the species was detected, an additional visit was made for the collection of ecological and population information. Surveys were conducted by daytime, but flashlights were used when necessary to spot the geckos. We recorded details of individuals (adults \& juveniles), number of live (viable) unhatched eggs, egg-laying sites and cave habitats. The basic statistics, including the arithmetic mean and standard deviation were calculated for different variables and are given as $\mathrm{X} \pm \mathrm{SD}$. The presence of other lizard species was also noted. Species identification was based on Smith (1935).

Using the data from our second survey undertaken in March-April, 2011 a total of 515 individuals were recorded of which 46 were juveniles. The highest number of geckos (344 individuals) was recorded from the reserve forests of the Gingee Range, Villupuram Forest Division. In Tiruvannamalai District, the golden geckos were recorded on both nonresidential private lands used by villagers for brick-making or small-scale agriculture and at Sathanur Dam (a tourism site). There were 108 individuals recorded from Melthiruvadathanur (Morambu) village in Thandrampattu taluk, 12 recorded from Karadi Parai and 34 recorded at Sathanur Dam (near the Crocodile farm). Seventeen were recorded at the Pilgrimage Centre at Kailasagiri (Table 1).

The species was encountered in rocky caves and in the crevices of large rock boulders during daytime (Fig. 1). The cave heights and lengths varied from $1.2-15 \mathrm{~m}$ and $0.5-17 \mathrm{~m}$ respectively. The rock boulder sizes varied from $1.5-15.5 \mathrm{~m}$ in height and $0.2-8 \mathrm{~m}$ in length. The distance from the nearest water 
source varied between $0.5-125 \mathrm{~m}$ with $63 \%$ of sites within a $30-\mathrm{m}$ distance. The geckos were encountered at an elevation range of 104-476 msl with $70 \%$ of them at an elevation of less than $200 \mathrm{msl}$.

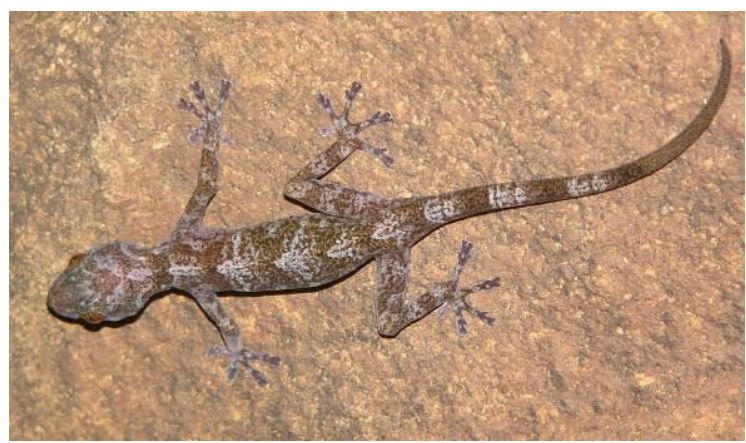

Figure 1: An adult Calodactylodes aureus at Siruvadi Reserve Forest, Gingee Range, Tamil Nadu.

A total of 242 egg deposition sites with hatched or unhatched eggs were found (Fig. 2). All surveyed caves and crevices where this species was detected had at least two egg deposition sites and the number of egg deposition sites varied from 2-30 at each site. The number of eggs in a cluster varied from 2 to $250+$ in an egg deposition site. Eleven unhatched egg clusters, a total of 42 unhatched but viable eggs were observed during the study period. The eggs were found during both surveys, starting from December 2010 to April 2011. The number of unhatched but viable eggs in each cluster varied from $2-8$ eggs. The size of the eggs ranged from 0.8 to $1.3 \mathrm{~cm}$ in diameter. The distance between the surface of the substratum (i.e., caves, crevices and boulders) and egg deposition sites ranged from 0.2 to 4.2 $\mathrm{m}$, and $31 \%$ of deposition sites recorded were within one meter distance from the surface of the substratum. The sites where the eggs were attached to the roof of caves were $2.12 \pm 1.26 \mathrm{~m}$ above the ground level, while in the crevices, eggs clusters were $0.87 \pm 0.53 \mathrm{~m}$ above the ground level. The golden geckos were mostly $(71.1 \%)$ found to lay eggs attached on the horizontal roof of caves and rock boulders with $28.9 \%$ of eggs laid on vertical rock surfaces.

Sympatric reptiles observed during the study included Psammophilus dorsalis, Hemidactylus sp., Hemidactylus triedrus, Eutropis carinata and Lygosoma cf. punctatus. Among these, $P$. dorsalis was more frequent than the others.
The present study confirms the presence of good breeding populations of Calodactylodes aureus in the Gingee, Sathanur Dam and Melthiruvadathanur (Morambu) areas of Tamil Nadu. The geckos were found in both vertical and horizontal crevices in the rocks and caves (Fig. 3). The temperature in these microhabitats was slightly less and the humidity higher than rocky surface areas as also reported by Rajashekhar \& Nanda Kumar (2007). Comparatively large numbers of geckos were spotted in the caves where the moisture content was high and there was seepage of water from the rocks. Even though Calodactylodes aureus is distributed up to $1000 \mathrm{~m}$ a.s.l. in Andhra Pradesh and Orissa (Chettri \& Bhupathy, 2010) we found all at low elevation except at Kailsagiri where the geckos were recorded at an elevation between $355-476 \mathrm{~m}$ a.s.1. The habitat characteristic of Calodactylodes aureus is very similar to the habitat of the Sri Lankan species, Calodactylodes illingworthorum, which is also found to occur between circa 125 to $800 \mathrm{~m}$ a.s.l, mostly in granite rock caves (Karunarathna \& Amarasinghe, 2011).

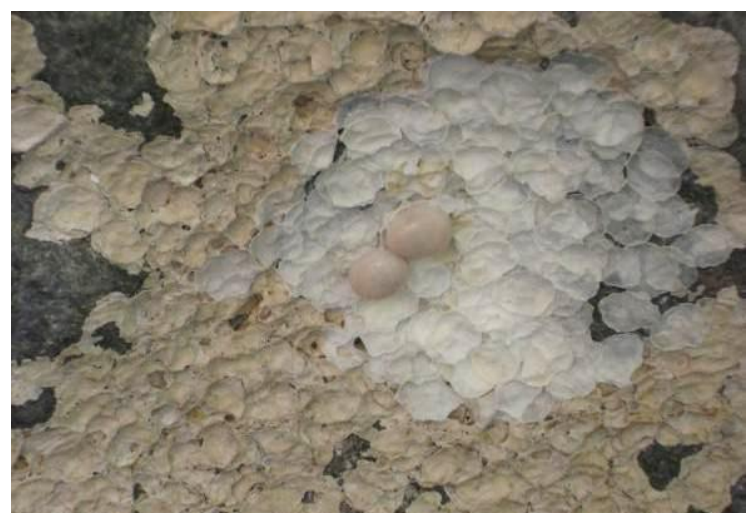

Figure 2: Communal egg deposition sites at a rocky cave in Muttakadu Reserve Forest, Gingee Range.

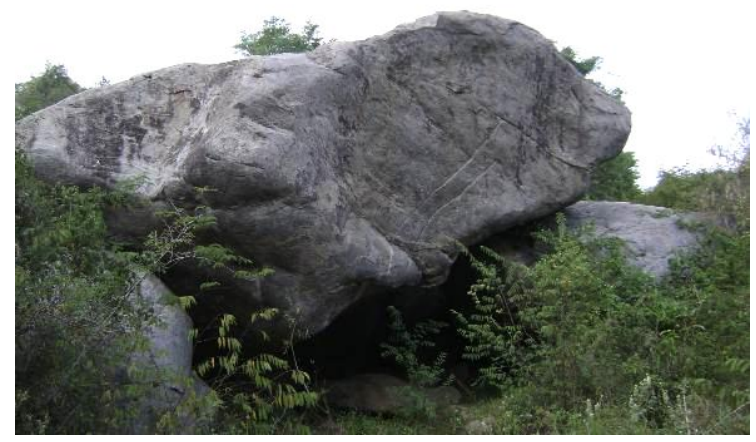

Figure 3: A habitat of Calodactylodes aureus, Cave temple of Alaiyathi Amman at Siruvadi Reserve Forest, Gingee Range, Tamil Nadu. 
According to Sreekar et al. (2010) this gecko prefers rocky areas with deep stream valleys. We also found that water is one of the essential aspects for choosing sites to live, as $63 \%$ of sites recorded were within 30-m distance of a water source. This may be related to prey abundance. Sreekar et al. (2010) reported that the gecko mainly feeds on insects and spiders.

The gecko has been reported to lay eggs in communal egg deposition sites on rocky surfaces (Bauer \& Das, 2000; Javed et al., 2007). In our study the eggs attached to the roofs of caves averaged more than two meters from the ground and the sites in which eggs were laid in crevices were less than one meter from the ground. This may be due to relatively lower predation pressure in crevices compared to the caves. Sreekar et al. (2010) found that sites that have eggs attached to roofs of caves averaging more than three meters from the ground and that sites in which eggs were laid in crevices had greater success relative to the eggs that were laid at a distance less than one meter from the ground. The gecko has been reported to lay eggs mostly on vertical rocks (Sreekar et al., 2010) but we found that $71 \%$ of eggs were laid attached on the horizontal roof of caves and rock boulders. In a few sites eggs were laid at an older egg deposition site. Sreekar et al. (2010) found that viable eggs were only found during late June to September. In our study we noticed viable eggs between December 2010 and April 2011. This indicates that the egg laying period may vary in different regions and can differ depending upon the climatic conditions, such as rainfall and humidity. In some places an unidentified species of sand wasp was found to make its nest on the previous egg marks of geckos.

We encountered the geckos in severely fragmented locations. A large number of individuals were recorded in the cave temples of Alaiyathi Amman, Duravapathy Amman, Durgai Amman and Pachai Amman in Siruvadi reserve forest of Gingee. With the exception of Melthiruvadathanur village and Kailasagiri Hill, the geckos were all spotted inside the reserve forests. At Melthiruvadathanur, the geckos were found on private land where the rock boulders were being blasted for stone quarrying.

The present study reveals that the distribution range of the Indian Golden Gecko is larger than previously known. This study adds new localities for this species at Gingee, Melthiruvadathanur village, Sathanur Dam and Kailasagiri Hill in Tamil Nadu. The species can be encountered in some other parts of Gingee and near Sathanur Dam. Due to undulating terrain and improper road networks we were not able to survey other places where the geckos may be found. Though commercial trade was considered as a major threat to this gecko (Molur \& Walker, 1998), we did not come across any such instance.

Table 1: Calodactylodes aureus observed in Tamil Nadu from December 2010 to April 2011

\begin{tabular}{c|c|c|c|c}
\hline \multirow{2}{*}{ District } & Area & \multirow{2}{*}{ Status of Area } & \multicolumn{2}{|c}{ No. of individuals } \\
\cline { 4 - 5 } Villupuram & Muttakadu & Reserve Forest & 36 & 110 \\
& Siruvadi & Reserve Forest & 80 & 119 \\
& Pakkamalai East & Reserve Forest & 72 & 115 \\
\hline \multirow{2}{*}{ Tiruvannamalai } & Sathanur Dam, Thenpennai River & Holiday Destination & 10 & 34 \\
& $\begin{array}{c}\text { Melthirvadathanur, } \\
\text { (Morambu) } \\
\text { Karadi Parai }\end{array}$ & Private Land & 44 & 108 \\
\hline \multirow{2}{*}{ Vellore } & Kailasagiri (Ambur) & Pilgrimage Centre & 20 & 12 \\
\hline
\end{tabular}

\section{Acknowledgements}

We are thankful to Geethanjali (DFO, Villupuram), Annadhurai and all other staffs of Gingee Range in Tamil Nadu Forest Department. We thank my colleagues and the academic staff of Wildlife Biology Department in A.V.C. College, Mannampandal. We are also thankful to Gokula Krishnan, Vinoth, Shek Dhavooth Ali, Valliyullah and Thiruvel for their various help during the time of survey. Finally we would like to thank John Rudge (UK) for editing the manuscript. 


\section{Literature cited}

Bauer, A. M. and I. Das, 2000. A review of the geckonid genus Calodactylodes (Reptilia: Squamata) from India and Sri Lanka. Journal of South Asian Natural History, 5 (1): 25-35.

Beddome, R. H., 1870. Description of some new lizards from the Madras Presidency. Madras Monthly Journal of Medical Science, 1: 30-35.

Chettri, B. and S. Bhupathy, 2010. Three little known reptile species from the Araku Valley, Eastern Ghats with notes on their distribution. Journal of Threatened Taxa, 2 (8): 1109-1113.

Daniel, J. C., B. Bhushan and A. G. Sekar,1986. Rediscovery of the Golden gecko Calodactylodes aureus (Beddome) in the Eastern Ghats of Andhra Pradesh. Journal of the Bombay Natural History Society, 83: 15-16.

Dutta, S. K., B. Mohanty and P. P. Mohapatra, 2005. Niyamgiri unraveled. Sanctuary Asia Magazine, October: 56-59.

Guptha, M. B., P. V. C. Rao, N. V. S. Prasad, S. R. S. C. S. Maddala, P. M. Babu and D. S. Reddy, 2012. Status of Herpetofauna in Seshachalam Biosphere Reserve, Eastern Ghats, Andhra Pradesh, India. World Journal of Zoology, 7 (2): 131-134.

Javed, S. M. M., A. Waran and F. Tampal, 2007. On the occurrence of Golden Gecko Calodactylodes aureus in Papikonda Hills, Eastern Ghats, India. Zoo's Print Journal, 22 (6): 2727-2729.

Kalaimani, A and A. Nath, 2012. A new locality and microhabitat usage by Calodactylodes aureus (Beddome, 1870) from Tamil Nadu, Eastern Ghats, Southern India. Herpetotropicos, 8 (1-2): $49-54$

Karunarathna, D. M. S. S. and A. A. T. Amarasinghe, 2011. Natural history and conservation status of Calodactylodes illingworthorum Deraniyagala, 1953 (Sauria: Gekkonidae) in south-eastern Sri Lanka. Herpetotropicos, 6 (1-2): 5-10

Molur, S. and S. Walker (eds.), 1998. Report of the Workshop "Conservation Assessment and Management Plan for Reptiles of India”. Zoo Outreach Organization and Conservation Breeding Specialist Group, Coimbatore, India: 175.
Nanda Kumar V. N., K. M. V. Lakshmi, M. Rajasekhar, S. A. Basha, T. R. Krishna, 2000. Survey of golden gecko, habitat analysis and conservation in Tirumala Hills. Ecology, Environment and Conservation, 6 (4): 435-439.

Rajshekhar, M. and N. V. Nanda Kumar, 2007. A new finding on the occurrence of golden gecko (Calodactylodes aureus) in the rock boulders near Vellore town. The Bioscan, 2 (1): 61-62.

Smith, M. A., 1935. The Fauna of British India, Including Ceylon and Burma. Reptilia and Amphibia Vol. II - Sauria. Taylor and Francis, London: xiii+440+1pl.

Sreekar, R., C. Srinivasulu, M. Seetharamaraju and C. A. Srinivasulu, 2010. Selection of egg attachment sites by the Indian Golden Gecko Calodactylodes aureus (Beddome, 1870) (Reptilia: Gekkonidae) in Andhra Pradesh, India. Journal of Threatened Taxa, 2 (11): 1268-1272.

Submitted: 7 Jan 2012, Accepted: 25 Jan 2013 Sectional Editor: John Rudge

\section{A. Kalaimani ${ }^{1} \&$ Anukul Nath ${ }^{1,2}$}

${ }^{1}$ Department of Wildlife Biology, A.V.C. College, Mannampandal, Mayiladuthurai, Tamil Nadu, India E-mail: manikalai16@yahoo.com

${ }^{2}$ Aaranyak, a society for biodiversity conservation Assam, India E-mail: anucool.nath5@gmail.com 